\title{
Research on the Common Problems and Corresponding Solutions for the Chinese-foreign Cooperative Education Management
}

\author{
Yun Zhang ${ }^{1}$ \\ ${ }^{1}$ DaLian Vocational \& Technical College, \\ Dalian,Liaoning,China
}

\begin{abstract}
In this paper, we conduct research and survey on the common problems and corresponding solutions for the Chinese-foreign cooperative education management. The training objectives of cooperation in running schools only to adapt to the society and education development rule for their healthy development. According to the economic development and social needs, the Chinese-foreign cooperation in running schools of talent cultivation, mainly reflected in the advanced nature of the program. Our research proposed novel solutions to the general problems and issues need to be solved for the Chinese-foreign cooperative education management which will be meaningful.
\end{abstract}

Keywords: Chinese-foreign Education; Common Problems; Management Solutions.

\section{Introduction}

Teaching is the basic of university activities. In universities, personnel work, student work, the general affairs work, some research work; Corresponding to this work, there are many different content of activity. In all these activities, normally regard teaching as the most basic activities, in other words, is teaching as the center, all activities should be around teaching. Talents training goal the basic specifications and quality of talent cultivation, determines the direction and level of talent training. The training objectives of education must conform to the society and the law of development of education itself [1-2]. The training objectives of cooperation in running schools only to adapt to the society and education development rule for their healthy development.
From the perspective of the external environment of higher education, the acceleration of globalization, various countries and regions of the world economy through the globalization of market and production of more and more closely interdependent and mutual influence. Higher education must take on task of training to participate in international competition talents. University cooperation in running schools through various forms and methods related to close cooperation with foreign universities, from the curriculum system, teaching materials, teaching methods, management, education concept, evaluation mode and teachers' comprehensive intuitive contact and understanding which is helpful to use the high quality resources to cultivate international talents [3].

Introduce foreign high-quality education resources is the key to the healthy and sustainable development of the Chinese-foreign cooperation in running schools. In cooperation with foreign high-quality education resources in the process of digestion and absorption, through absorbing the merits of each other and their education teaching conditions can be effectively improved and ascend. From the development of cooperation education in running schools and the current situation look, Chinese-foreign cooperation in running schools can develop so fast, is that it adapt to the needs of talent market. According to the economic development and social needs, the Chinese-foreign cooperation in running schools of talent cultivation, mainly reflected in the advanced nature of the program, teaching content and teaching form of novelty, the management pattern of advanced, truly reflects the wide into 
severe out entrance system of graduation. This with our higher education at present relatively fixed teaching plan, teaching content and teaching form of relatively old, relatively backward management mode and school graduated easy entrance system form bright contrast [4].

Currently, the Chinese-foreign cooperative education management has lots of drawbacks which will be discussed in the following. (1) In a sense, Chinese-foreign cooperation in running schools internal system problem is mainly manifested in the independent setting of cooperative education institutions. (2) As a secondary school of Chinese-foreign cooperation in running schools entity is under the leadership of the primary school of education, to a large extent national tradition of our country planned economy mode to do the thinking and way of management of higher education, management mode, education teaching characteristic is bright, the lack of the innovation of the management system and operation mode [5-6]. (3) The development of the discipline of Chinese-foreign cooperation in running schools lack of long-term planning. (4) Due to the understanding of the role of Chinese-foreign cooperation in running schools, status and the cooperative education institutions in running, some can't work together, rapidly forming features.

To optimize the current management methodology, in this paper, we research on the common problems and corresponding solutions for the Chinese-foreign cooperative education management. From the point of the above forms of cooperation in running schools, cooperative education is helpful to integrate and use a variety of resources to participate in the cooperation in running schools in each benefit main body. For students, transnational education can get a foreign degree or diploma at relatively low cost, and with the international standards of knowledge and practical experience, enhance the competitiveness of their employment. Cooperation in running schools in the school system is solved in the process of the reform of higher education in our country the realization of the investment main body autonomy, and through the market to test and adjust the investment efficiency. Therefore, cooperation in running schools has the hopes to find a bottom-up diversified road of the reform of higher education running system. In the following sections we will discuss the issues in detail from the basic layer and higher management pattern layers.

\section{The Problems and Corresponding Solutions}

\section{The Basic Knowledge on Education} Management. In recent years, the popular practice teaching management has made some progress and achievements, but in the higher education under the new situation of rapid development, with the school scale expands rapidly, the overall level of higher education institutions has been continuously improved, the practice teaching management still exist the following problems: concept lag, heavy "tube" light "reason", think that management is leadership, lack of service consciousness. Process is not standard, management positions at random and blindness is larger, the lack of quality consciousness; Mechanism is not sound, lack of innovation evaluation, motivation, evaluation, mechanism of choose and employ persons. System is not perfect, most colleges and universities has not yet formed perfect management system. Teaching management is the activity of school system. In this thesis, the traditional teaching management mode more is the school system as a teaching management to carry out the normative proposition to understand, seldom go to reflect prevailing conditions of the school as a teaching management system of moral problems, and potential impact of teaching management. Responsibilities are not clear, the practice teaching management in college, personnel, educational administration, equipment, general services and other units, departments of management responsibility is not 
clear, increasing the friction between the departments or positions, shuffle, evasive. Evaluation is not scientific, independent practice teaching evaluation system has not yet establish or improve, to practice ability of teachers and the students' ability to make a fair and scientific evaluation. Strengthening the practice teaching management is a project which is in addition to teaching unit and also involves many administrative functions.

Diversification of teaching organization form and teaching activities with man is the major body in the institutional environment. However, the current people watches local undergraduate colleges and universities teaching quality and talent training quality problems, to some extent, has reflected the teaching deviation from the fundamental direction of education. There is no denying the fact that mission teaching must bear duty of teachers, because the teacher is teaching. Teachers are responsible for the duty, can ask for teachers' teaching behavior of the school system. Recognize the inherent relationship of the school system and teaching management, for through the school system to strengthen the teaching management is still meaningful. School system as members of the school rules and interest relationship system of rules, the formation of school education, teaching management system for schools of the statute, in a sense is the need of job of teaching of specification. Because, the body of the teaching management of teachers, students, school leadership, teaching management personnel, in the process of interaction with each other in complicated interpersonal relationship, interest contradiction and conflicts exist. To coordinate interpersonal and interest relations in the work of teaching, teaching management become necessary.

The Common Problems of Chinese-foreign Education Management. Chinese-foreign cooperation in running schools is refers to the foreign education institutions with Chinese education institutions within the territory of China cooperation held by Chinese citizens as the main object of recruit students of education and teaching activities, this is a product of globalization of education is the expansion of the education in China and supplement. Chinese-foreign cooperation in running schools in colleges and universities is an important means of promoting we get foreign excellent education resources. Chinese-foreign cooperation in running schools of institutions of higher learning how to health and safely running, is a problem that must be carefully study and treat. Chinese colleges and universities through education administrative department at or above the provincial level to assess the qualifications of foreign cooperation colleges, in order to ensure the foreign schools have legally registered abroad, is listed as national education degree certification scope by the administrative department of the school, is also a fundamental peer cooperation with domestic colleges and universities level of colleges and universities. And on this basis to choose the school has a long history, as far as possible, as a partner, a world famous foreign colleges and universities. These diplomas issued by the foreign colleges and universities in our country should also with diplomas in their home countries with full consistency and credibility.

Chinese-foreign cooperation in running schools to cultivate students, in part, is to study and work abroad in the future. But most are in the domestic employment, so both sides of cooperation in running schools must according to this characteristic, combined with their professional curriculum system, through mutual consultation, scientific and reasonable professional curriculum develop good cooperation project. Should not only focus on the introduction of foreign professional core courses and teaching materials, but not blindly copying foreign curriculum system, to insist on open course with Chinese characteristics, make our country's higher education personnel training idea and the basic requirements throughout the training course, the students eventually become 
professionals can meet the need of employment at home and abroad.

Most of the course teaching is the teacher at the same time more than the specified materials. Foreign teaching, most teachers fusion all family point of view, after finishing the lecture, each class to students to distribute copies; Students read after class teacher assigned bibliography, and access to a lot of data. Under the teaching mode still adopt the thinking of Chinese, according to China's training schemes introduce the foreign original teaching materials, actually is bad which determine the introduction of this teaching material as well. Chinese-foreign cooperation in running schools in the use of bilingual teaching in foreign language teaching materials, the real goal is generally the ideal goal of bilingual teaching of students. Based on this, the development of editing the teaching material is especially important in Chinese-foreign cooperation in running schools. And develop the teaching material is compiled, writers is the key. Mass sent according to the present situation of our higher education, teachers college study abroad do not have objective conditions, while the Chinese-foreign cooperation in running schools $r$ convenient teacher exchange opportunities.

The Corresponding Solutions to the Problems. Cooperation in running schools can directly is developed country advanced educational philosophy, teaching methods and teaching management experience. China's higher education scale development space is very large. More room to improve the overall level of education in our country. Our higher education to meet the needs of social development for talent, we must make the trained talent to adapt to the trend of economic globalization. This needs our higher education learning and absorbing foreign advanced educational philosophy and teaching management experience and education technology, so as to improve their ability of running a school. Host is the purpose of cooperation in running schools with the power of abroad to developing domestic much-needed talent, so schools should adhere to the "is given priority to with me", grasp the managerial ownership, the cooperative object to carry on the strict examination and approval, to ensure high level cooperation objects and be able to use its cooperation to promote our ability of running. Cooperation in running schools must adhere to the correct direction of running. Keep a clear head, to prevent some countries partners and domestic operators too much economic interests. The Chinese-foreign cooperation in running schools project is incorporated into the national enrollment plan for institutions of higher education schools in the sunshine, and in the same area with the university's other professional arrangement in the same batch, to ensure the quality of Chinese-foreign cooperation in running schools, at the same time ensure a transparent and fair admissions process. For Chinese-foreign cooperation in running schools do not issue the domestic diploma project, the entrance should also set up a certain threshold, or through a unified proposition examination merit of colleges and universities, which are held in or through foreign language relatively fair selection test, interview and guarantee the seriousness of human requirements.

Chinese-foreign cooperation in running schools project can be safe and stable operation, in addition to establishing should the organization system and unified in student management system, also held in the project of colleges or departments set up specialized project management agencies, targeted to carry out some special education management work. Good jobs to students is the success of the final inspection standard, it can make the way of cooperation in running schools to the benign development path, the results of cooperation in running schools would get students and parents and social recognition and support from all walks of life, for the firm the confidence of the Chinese-foreign cooperation in running schools is necessary. Proved by substantial introduce foreign 
high-quality education resources, the Chinese-foreign cooperatively-run school can enhance the level of school grades and quickly which will be meaningful for the current education pattern and management.

\section{Conclusion}

In this paper, we conduct research and survey on the common problems and corresponding solutions for the Chinese-foreign cooperative education management. Chinese-foreign cooperation in running schools is our country after the reform and opening-up policy in the field of international education exchange and cooperation between China and the emergence of new things which is also under the background of economic globalization the Chinese education in line with international standards of a beneficial attempt and exploration. With foreign well-known university to carry out various forms of cooperation in running schools, Chinese-foreign cooperatively-run schools to introduce and grafting foreign brands of famous university, a high level of professional disciplines and the curriculum. In conclusion, our research is meaningful in the perspective of enhancing the education management.

\section{References}

[1] Zhou G. The Practice and Features of English Teaching in the Chinese-Foreign Cooperative Education Project of Our School[J]. Science Education Article Collects, 2014.

[2] Shao, X. Y. (2014). An initial probe into chinese-foreign cooperation in running universities in the level of four-year university education. Journal of Jianghan University.

[3] Choi, S. B., \& Williams, C. (2014). The impact of innovation intensity, scope, and spillovers on sales growth in chinese firms. Asia Pacific Journal of Management, 31(1), 25-46.

[4] Fung, D. (2014). The influence of ground rules on chinese students' learning of critical thinking in group work: a cultural perspective. Pedagogy Culture \& Society, 22(3), 337-368.

[5] Frambach, J. M., Essen, E. W., \& Philip Beh\& Cees P.M. van der Vleuten. (2014). Quiet or questioning? students' discussion behaviors in student-centered education across cultures.

[6] Li M. Employee Characteristics and Management[J]. Understanding Chinese Firms from Multiple Perspectives, 2014. 